\author{
Geert R. Teisman \\ Erik-Hans Klijn \\ Erasmus University Rotterdam, Netherlands
}

\title{
Partnership Arrangements: Governmental Rhetoric or Governance Scheme?
}

\begin{abstract}
It has become popular to advocate partnership arrangements. Such partnerships may be seen as new forms of governance, which fit in with the imminent network society. However, the idea of partnership is often introduced without much reflection on the need to reorganize policy-making processes and to adjust existing institutional structures.

In this contribution, we discuss the ambiguity of partnerships. An empirical basis is provided by means of an analysis of the policy making on the expansion of the Rotterdam harbor. This case indicates that although new governance schemes are being proposed and explored, they still have to comply with the existing procedures in which they are imbedded. Governments especially are not prepared to adjust to governance arrangements. Policy making continues to be based on selfreferential organizational decisions, rather than on joint interorganizational policy making. This raises questions about the added value of intended cooperative governance processes.
\end{abstract}

\section{Looking for New Forms of Interorganizational Governance}

The involvement of all kinds of organizations in joint decision making has received a great deal of attention lately. This search for cooperation can be seen in all domains of societal decision making: between government organizations, between government and citizens, and, more recently, also between government organizations and private-sector organizations. Intergovernmental interaction has been the subject of a number of studies on planning and decision making (Mayntz and Scharpf 1973; Rhodes 1996). While interactive decision making was also one of the main topics of the 1990s (Daemen and Schaap 2000). Public-private partnerships are gaining support as new forms of governance (Osborne 2000).

This call for governance, cooperation, and partnerships, however, does not directly lead to major shifts in day-today decision making. Partnership projects are not easy to realize. Verbally, much has been made of the potential benefits of cooperation. The term "partnership" has clearly penetrated the language games played by politicians and governors. For instance, the Labour prime minister of Great Britain, Tony Blair, and his Cabinet have frequently referred to "partnerships" when implementing their policies.
The partnership concept stands for the New Labour, which works with society rather than directing it from above. Partnership gives the government a new legitimacy: the efficiency of the private sector and the involvement of civil society (for partnerships, New Labour, and contradictions, see Falconer and McLaughlin 2000).

However, looking more concretely at everyday reality, we find there seems to be a scarcity of projects set up jointly by public and private actors. For instance, the well-known Public Finance Initiative in the United Kingdom, set up by

Geert R. Teisman is a professor of public administration at Erasmus University Rotterdam. He holds degrees in transport and sociology. His PhD thesis concerned the phenomena of complex decision making, especially in the field of urban development and transport. Recent research focuses on intergovernmental relations, public-private partnership, and interactive decision making. These themes are studied from the perspective of process analysis and process management. Email: teisman @fsw.eur.nl.

Erik-Hans Klijn is an associate professor of public administration at the Erasmus University Rotterdam. He achieved a degree in public administration. His PhD concerned the influence of network rules on restructuring postwar housing areas. His recent research focuses on complex decision making and institutionalization processes in networks, public-private partnerships, and institutional design. He has published in Administration and Society (1996, 2001), Public Administration (1995, 2000), and Public Management Review (2000, 2002). Email: klijn@fsw.eur.nl. 
public actors, is a contracting-out scheme rather than a partnership (for the distinction between contracting-out and partnerships, see Klijn and Teisman 2000). In the Netherlands, we see only a few cases where we can really speak of a public-private partnership. And even in several of the so-called Partnerships Key Projects that have been adopted by the Partnerships Center of the Ministry of Finance, one may question the level of partnership.

While there is an intensified interaction between public and private partners, there is little joint decision making and continuity in cooperation. In fact, the use of the term "partnership" does not immediately imply a change from unilateral to joint decision making, as opposed to experiences in the private sector, where many joint ventures and strategic alliances have actually been established (Faulkner 1995; Böttcher 1995)

In this article, we explore the factors that account for the gap between dream and reality with regard to partnership as a governance scheme. Our insights and conclusions are based on an analysis of a prominent case in the Netherlands: the planning and decision making of Mainport Rotterdam, one of the leading harbors in the world. Due to the globalization of the production chains of many firms, the amount of goods transports worldwide is growing. In 1995, Mainport Rotterdam handled some five million containers; in 2020, this will be at least 10 million and possibly more than 15 million. This raises the question of how to deal with this growth. In terms of economy, many stakeholders are in favor of growth and, therefore, advocate reserving additional space reservations for new industrial areas. This, however, implies the realization of a new polder in the river delta and partly in the North Sea. This solution has been questioned, not just by various environmental groups, but also by public authorities responsible for spatial planning. Even some of the economy-oriented actors are not in favor of expanding the port, questioning the added value of the traditional transport sector. All the critics advocate shifting from a "mainport" to a so-called "brainport."

Before discussing this case (section 3) and the lessons we can learn from it (section 4) in more detail, we will first address the reasons for the rise in pleas for partnerships. Partnerships in general and public-private partnerships in particular can be seen as new governance schemes, which aim to manage the increased interdependencies between all kinds of societal actors. The partnership concept may be linked to the trend toward network forms of governance, in which public actors take their interdependencies with other actors into account and try to solve governance problems through cooperation rather than through central steering and control (Susskind and Cruikshank 1987; Sinnig 1995; McCarthy 1998).

\section{The Need for Governance Schemes}

Despite the problems they entail, public-private partnerships are pointed out as worthwhile schemes over and over again. Partnerships are seen as the best way, in the end, to govern the complex relations and interactions in a modern network society. As an argument in favor of public-private partnerships it is said that the intertwining of the public and private sectors calls for new forms of governance (Castells 1996). We will elaborate on this argument.

\section{Beyond Markets and Hierarchies: A Theory of Cooperation}

We assume that the classic separation between market and hierarchy or between public and private sector is disappearing. The validity of this assumption can be illustrated in many ways. The first one that springs to mind is the fact that public and private actors are becoming increasingly dependent on each other. This has been shown in recent theoretical and empirical work on governance and also by the discussion on the public-private distinction (Marsh and Rhodes 1992; Kickert, Klijn, and Koppenjan 1997).

But one can also observe that the organizational mechanisms that are traditionally labeled as part of either the public or the private sector (and are often at the same time labeled as hierarchy and market) are changing. Competition has become part of government regimes, and cooperation and coordination have become a part of network management in the private sector (Böttcher 1995). Firms are operating within "industrial networks," where they depend on a range of other firms for the manufacturing and sale of their products. Within these networks, firms seem to rely on forms of relational contracting rather than on simple market transactions, or on hierarchically internalizing activities as survival strategies. There is a growing body of literature that tries to account for these developing relations between firms and addresses the question of how these industrial networks function and what advantages they have to offer (Miles and Snow 1986; Hakansson and Johansson 1993; Lundvall 1993; Alter and Hage 1993). It is stated that interorganizational chains and networks are a reaction to the rising expectations and demands of clients (Martin 1994; Ohmae 1994).

In fact, governments are faced with the same developments in society. They are also becoming more and more dependent on private and semiprivate actors for implementing their policies. In this respect, we may say that governmental organizations and actors are functioning in similar networks (see the large body of literature on this topic: Hanf and Scharpf 1978; Rhodes 1988; Marsh and Rhodes 1992; Kickert, Klijn, and Koppenjan 1997; Teisman 2001). This makes the implementation of policies and projects a complex issue, requiring cooperation with various actors. 


\section{The Governance Debate as a Twofold Question: Why Needed and Why Not Established}

There is, however, a major difference between the public and the private sector. The public sector is based, to a far greater extent, on hierarchical demand mechanisms that are controlled by the top administrators and politicians. They can define demands of society on an aggregated level without the need to trace this demand back to individual demands. It may be argued that many of the hierarchical mechanisms in the public sector do not fit in well with situations in which the government has to achieve its goals. Implementation problems are legendary (see the classic Pressman and Wildavsky 1984). At the same time, however, the government is unwilling to abandon its formal superior position, mainly because hierarchy is the only representative democracy model we are familiar with that has shown its quality. And due to a lack of alternatives, governments and politicians tend to adhere to the formal procedures based on principles of hierarchy. Within this hierarchy, it is the politicians who impose the demands, not society. This diagnosis brings us to a twofold question: The first refers to the need of new theories and practices in terms of governance arrangements, and the second refers to the need for theories about the inability to establish new governance arrangements. By dealing with these two questions at the same time, we are able to better understand the splits that many governments find themselves in.

- If markets increasingly resemble networks, and if governmental agencies have also become increasingly dependent on network cooperation for their own efficiency and effectiveness in meeting societal demands, what does this imply for governance schemes in terms of partnership relations? What could these new schemes look like?

- If, however, governments continue to stick to their traditional procedures based on hierarchy and the primacy of politics as the best representative arrangement we have in Western society, what then are the chances of success for partnership schemes? Can we think of effective combinations of partnership and hierarchy?

To deal with these two questions, we will start our argumentation and exploration with statements that have been made recently about network society and network management (Castells 1996; Kickert, Klijn, and Koppenjan 1997; Teisman 2001). We postulate three features that should be incorporated into theorizing about the implementation of new governance schemes:

1. The achievement of the goals of each individual actor requires activities by the other actors; mutual adjustment is an important prerequisite.
2. The knowledge and resources necessary for achieving the desired outcome are distributed among different actors. The importance of resources is not a given, but depends on the value attributed by others (Scharpf 1978, 1997). Moral support, for instance, seems to have become an important resource in decision making. The scattered control of various resources creates a "world in which nobody is in charge" (Bryson and Crosby 1992, VI).

3. Complexity is a result of the interaction and negotiation processes between different actors, whose resources are indispensable for a joint undertaking. All these actors bring their own perceptions and strategies (Lissack and Gunz 1999; Teisman 2000; Klijn, Koppenjan, and Termeer 1995).

A crucial question now is how organizations in general and governments in particular will cope with these developments. We assume the perceptions and interpretations of these developments are the main factors that predict government's reactions. It may, for instance, be assumed that if complexity (several actors involved, a variety of resources that should be combined, and a variety of perceptions and solutions) is seen as a threat by governmental organizations and politicians, proposed partnership arrangements are likely to be quickly transformed into traditional contracting-out schemes. In contracting-out schemes, the government can go on using its existing, well-established procedures of internal decision making. The interaction with the private sector can be defined in terms of a principal-agent relation. The government decides what it wants and the private sector decides what it can deliver and at what price.

The insights resulting from our search into the way governments deal with the partnership phenomenon can be summarized as follows:

- The establishment of network society and, more specifically, the rising expectations on the part of citizens challenge the existing processes of decision making, both in terms of participation and quality of the outcome (Castells 1996; Teisman 2001).

- In response to the rising expectations, the private sector has become more consumer oriented and, as a result, numerous interorganizational production chains, alliances, and partnerships have been established (Hoogervorst, 1998).

- Due to the different way that demands are defined in the public sector, governments have only recently begun to talk about and carry out experiments with cooperation and partnership.

- These same governments, however, still seem to be dedicated to their own procedures, rules, and principle of control; for this reason, they try to fit partnerships into the mold of traditional policy-making procedures. 


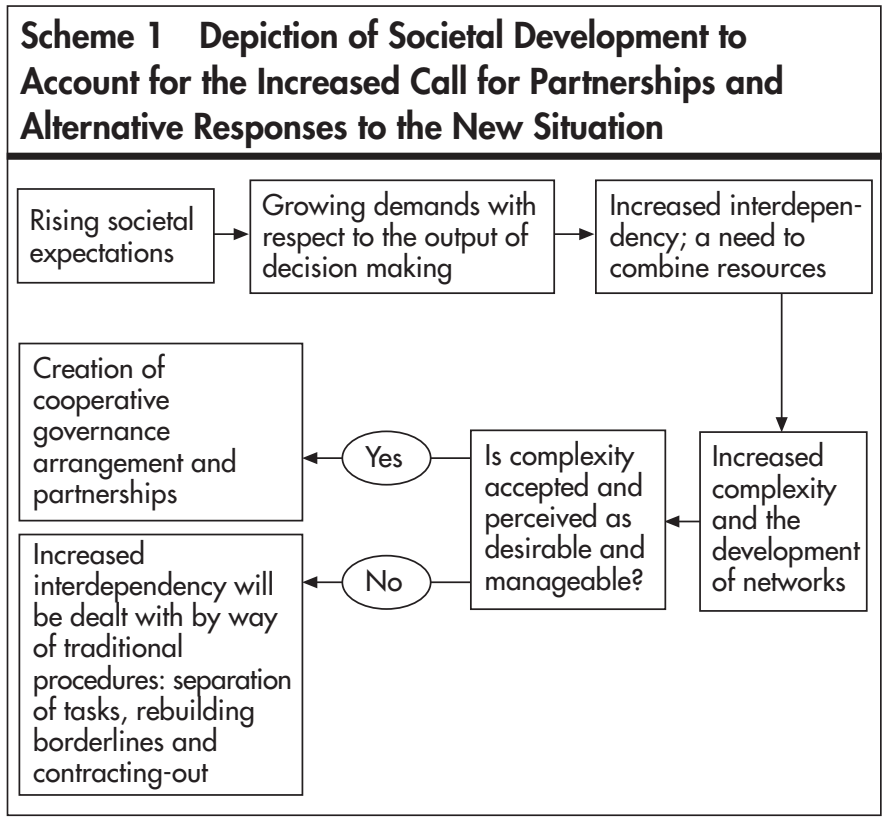

- If governments do not appreciate the complexity that partnerships entail, in the end they will probably opt for traditional contracting-out schemes, despite all the rhetoric about partnerships and third ways (Giddens 1998).

These steps of reasoning can fit into a scheme that depicts the societal development that the private and public sectors are facing and the two different responses that can be foreseen, based on the perception governments have of the phenomena of complexity.

In the next section, we will present empirical material to elaborate on the question of the choice governments make with respect to complexity and governance arrangements such as partnerships. The case affirms statements often made that processes are becoming more complex due to societal demands. These demands are no longer represented by a single governmental organization. A whole ecology of governmental organizations, as well as economic, social, and environmental groups, are seen as important as representatives (though not elected in the traditional sense) of societal needs and ambitions. The participation of all these organizations complicates policymaking processes.

The case also indicates that public authorities have recognized the phenomenon of rising demand. They also recognize the need for support from others, which, in turn, will create new and complex arrangements and processes. Therefore, the first part of our train of thought, illustrated in scheme 1 , seems to be valid. The key question is to what extent governments are ready and able to deal with this complexity. The case clearly indicates that the demands imposed upon governments by society call for partnerships to be established. The case also indicates that existing governmental procedures and positions still force all three iden- tified types of partnership arrangements (intergovernmental, citizen participation, and public-private partnership) back into traditional arrangements such as division of tasks, hearings, and contracting out.

\section{Complex Policy Making with Regard to the Mainport Rotterdam}

The Rotterdam Harbor developed rapidly after the Second World War. In the period of reconstruction, from 1945 until the early 1980s, the development of the harbor was not under discussion. It was seen as a keystone of economic development. The policy-making process was not complicated by all kinds of opposition, and therefore relatively simple. The alderman of the Council of Rotterdam and the Rotterdam Harbor Authority, a department of local government, took the main decisions. The National Department of Transport was responsible for the infrastructure and was the sponsor of substantive investments in the harbor. The first sea polder, the so-called Maasvlakte I for industrial activities, was realized under this regime. The Harbor Authority defined the need for new industrial areas and national government paid for it. Its interesting to see that the investment was based on the assumption that the Maasvlakte I would be needed for new chemical industry (blast furnace). When the polder was ready for use, however, this need did not exist anymore. This mismatch, however, did not lead to any governmental crisis. And after a few years, fortunately, a new activity appeared on the scene: container shipping. The container trans-shipment activities were located on the Maasvlakte.

In our case study, we present a reconstruction of the decision-making processes in the last decades. We distinguish three rounds of decision making (for the method of decision-making rounds, see Teisman 2000). The first round of decision making, labeled Space and Environment (ROM), started in the 1980s. The ROM arrangement can be seen as one of the first efforts to organize interaction between several public authorities that were responsible for a specific territory. In this case, the area was the Rijnmond region, which covers Rotterdam and 22 other public and private organizations. In 1993, these 23 organizations signed the ROM-Rijnmond Covenant. They agreed to set up some 50 projects in order to realize a twofold objective. It was their aim to stimulate economic growth within this region and improve the living conditions of its inhabitants. The Maasvlakte II project, possibly needed if an ongoing economic expansion created a shortage of industrial areas, was also covered by the ROM covenant. In several ways, this project, proposed by the Harbor Authority, was a copy of the Maasvlakte I, not only technically, but also in terms of governance. 


\section{Three Generations of Governance Arrangement in Policy Making}

To work out the details of this plan, a project organization was set up in 1994. In December 1995, this organization, whose main actors were the Rotterdam Municipal Port Authority and members of the State Water Board, concluded that the harbor would be faced with a considerable lack of space for new economic activities in the near future. The construction of a new polder in the sea (Maasvlakte II, covering some 2,000 hectares) would be needed. The organization advised defining the project as one of major national importance in view of its significant consequences in the field of economics, spatial planning, and the environment. Thus, the administrative council for the Rijnmond area concluded in December 1995 that a discussion would have to take place at the national level about the problem of space in the Rotterdam port area. The Cabinet took up this proposal in the context of its views on handling large-scale projects, which also led to widening the scope of the project. From a project intended to expand the Rotterdam port area, it became a project intended to explore the possibilities of expansion and the way these would correspond to other objectives and uses of space.

In other words, a decision was made to widen the scope of the project, both in terms of the number of actors involved and the number of issues covered by the project. This round of decision making became known as VERMVErkenning Ruimtebehoefte Mainport (exploring spatial needs mainport). A lot of new actors were involved in this process, especially citizens and local and regional groups. The results of this round were handed over to the government in the summer of 1997. Several months later, the national government decided to start a third round of decision making, the so-called PMR (Project Mainport Rotterdam). This round can be characterized in different ways, but the main theme we will deal with here is the attempt made during this round to combine public decision making with private development.

\section{Round I: A Public Partnership Approach: Combining Physical Planning, Environmental Policy, and Economic Development}

The integrated, area-oriented policy was a new concept formulated in the Fourth Report on Spatial Plan-

\section{Scheme 2 Policy-Making Rounds on the Development of} Mainport Rotterdam

\begin{tabular}{|llll|}
\hline Three rounds & $\begin{array}{l}\text { Public partnership } \\
\text { approach (ROM) }\end{array}$ & $\begin{array}{l}\text { Popular participation } \\
\text { approach (VERM) }\end{array}$ & $\begin{array}{l}\text { Public-private } \\
\text { partnership } \\
\text { approach (PMR) }\end{array}$ \\
$\begin{array}{l}\text { Period } \\
\begin{array}{l}\text { Characteristics of the } \\
\text { governance scheme }\end{array}\end{array}$ & $\begin{array}{l}\text { Joint decision making } \\
\text { between public } \\
\text { authorities }\end{array}$ & $\begin{array}{l}\text { Interaction between } \\
\text { governments, citizens } \\
\text { and societal groups }\end{array}$ & $\begin{array}{l}\text { Interaction between } \\
\text { governments and } \\
\text { private organizations }\end{array}$ \\
\hline
\end{tabular}

ning of the Ministry of Housing, Spatial Planning and Environmental Policy (December 1988). Due to all kinds of implementation problems in both spatial planning and environmental policy, a search was begun for new and more effective schemes (Tatenhove 1993, 137). Keywords of the ROM approach-Ruimtelijke Ordening en Milieu (Spatial Planning and Environmental Policy) —were regional orientation, integration, cooperation, and feasibility (Tatenhove 1993, 145). In the Netherlands, 11 ROM regions were selected (Ministerie van VROM 1990,14). One of the appealing new schemes was the integrated area approach, which had two main characteristics:

- Integration of content: an explicit effort to integrate spatial and environmental policies. These two policy fields had quite different characteristics. Several of the instruments of environmental policy, however, were counterproductive in terms of spatial planning.

- Administrative integration: an explicit effort to set up some form of collaborative decision making between the different layers of government.

The ROM scheme can be seen as one of the first efforts in spatial planning to set up a dedicated scheme for decision making on an ad hoc basis. To kick off the ROM project, an administrative agreement was drawn up between all the authorities (and other parties) involved in decision making in this specific area, in which the various partners set out their goals and main principles.

In the next two years, a joint plan of action was developed (ROM project Rijnmond 1993), followed by a final covenant (December 1993). Two ministers, one deputy minister, the province, 15 mayors, and three regional economic agencies signed this covenant. After this, the implementation of this joint undertaking was begun. The covenant mentioned the realization of Maasvlakte II as one of its projects, and a project organization responsible for its implementation was set up. In 1995, this organization presented a report on Maasvlakte II. In 1996, the Cabinet decided to start a separate decision-making process on Mainport Rotterdam.

In 1997, ROM-Rijnmond was evaluated, and a new covenant was signed. It is interesting to see that from that point onward, the term "project" was replaced by the term "program." It had become clear to the people in charge that ROM was not a project, and, for this reason, it could not be managed as such (ROM-Rijnmond, Drawing Up the BalanceDe Balans opgemaakt, November 1997). The new covenant mentions the PMR as its first and most important project under the heading "Space for the Mainport." 


\section{Round II: Toward a Widening of Scope: The Interactive Approach of Policy Making}

The Cabinet's decision in April 1996 started the so-called VERM round. This round of decision making was based on the proposal made by the Scientific Council for Government Policy (Wetenschappelijke Raad voor het Regeringsbeleid), formulated in its report "Decisions on Large-Scale Projects." The VERM round ran from April 1996 until the summer of 1997. It became one of the first major infrastructure projects that was explicitly described as a type of decision making that would be handled interactively. The twofold objective stated in the ROMRijnmond Covenant was adopted. VERM's purpose was to offer a solution to the possible lack of space in the Rotterdam port area and to improve living conditions within the surrounding environment. Thus, economic ambitions would have to be combined with environmental goals.

To organize this open planning process, a new project group was once again set up, in which officials from four ministries took part (Traffic and Waterways, Economic Affairs, Agriculture, Nature Control and Fisheries and Housing, Spatial Planning and Environmental Policy). In the period from May 1996 to mid-1997, an interactive process was initiated, in which the usefulness of and need for expansion of the Rotterdam port area and possible alternatives were discussed with many of the parties involved. During brainstorming sessions with experts on content and process development, sounding-board groups, and workshops, many actors were consulted, and the nature of the spatial problem and its possible solutions, also outside the Rotterdam area, were discussed (Klijn and Koppenjan 2000).

The report drawn up by the project group, on the basis of this interactive decision making, was published in mid1997. The findings of the project group were that lack of space could be seen in three sectors in particular: containers, chemistry, and distribution. However, these data became available only at a late stage of the process, so it did not play a dominant role in the workshops, where discussions were held with several of those involved. Basically, there were three alternatives:

- The zero option: No expansion, because the economic advantage had not been convincingly proved. Economic development would have to focus on other (more environmentally friendly) sectors.

- Expansion by increasing port activities within the existing area: New functions would have to be incorporated into the existing space by means of restructuring. In addition, space would have to be made available in other areas. This would make it possible to handle container transport in Vlissingen/Terneuzen. Several regions indicated they would have space to cope with the growth of chemistry.
- Increasing port activities by expanding the port area: Such expansion plans existed in several regions. Maasvlakte II could be designed in a number of different ways. A small polder could be constructed to handle growth in the container sector. A larger polder could also be constructed to cope with the lack of space in all sectors. The general opinion in the workshops was that the polder area should be kept as small as possible. There was also a preference for northward expansion, which would cause fewer harms to the natural environment than expansion southward. The option of expanding into the sea was not studied further.

After the results of VERM were handed over to the national government, the further preparation of the Cabinet decision took place along the usual official channels. During this preparation, the findings of the VERM project group were used only sporadically. The decision of the Cabinet in 1997 was more in line with existing opinions at the beginning of the interactive process than with the contents of the VERM debates. Several characteristics of the process contributed to this result:

- In contrast to the ROM round, no explicit attempts were made to incorporate the interactive process into the policy-making procedures of the national government.

- The activities of supporters of the Maasvlakte II solution were neither stopped nor incorporated into the VERM process.

- Government had no experience with the new scheme proposed by the Scientific Council for Government Policy and had not developed a clear concept of the implications of interactive decision making for existing procedures.

\section{Round III: In Search of Private Financing and Involvement}

On June 14, 1997, the Dutch Cabinet decided to initiate a new round of decision making. This decision was called a project decision, in compliance with the Scientific Council for Government Policy's proposals. It was the official conclusion of the VERM round, even though the Cabinet did not decide to what extent a new polder would be necessary. The third round was heavily embedded in the existing national procedures of decision making in the field of spatial planning and environmental policy: the spatial core decision procedure (PKB) combined with an environmental impact study. For this reason, the Cabinet used the term PKB+. In this round, the ambition to combine economic development with upgrading spatial and environmental qualities was consolidated (twofold goal).

At the same time, however, the Cabinet was urged by Parliament to pay specific attention to the possibilities of public-private collaboration (motion proposed by the 
Labour Party in Parliament). In practice, however, the public authorities, more specifically the new project organization on Mainport Rotterdam, took the initiative: PMR. This project group consisted of representatives from the four ministries, together with the Rotterdam Regional Authority, the municipality of Rotterdam, the province of SouthHolland, and the Ministry of Finance. The last-named actor entered the Mainport arena because it was the initiator of the Knowledge Center on Public Private Partnership. Ten other municipalities involved in ROM, however, did not participate in this scheme (see Mainport Development Rotterdam Starting Memorandum-Startnotitie Mainportontwikkeling Rotterdam 1997). A private-involvement study project was set up in October 1998, in which a consortium of several public and private parties explored the possibility of private involvement in realizing parts of the Mainport Rotterdam project.

An interim report indicated that it was important to involve private parties at an early stage (On Board TogetherSamen aan Boord 1999). Three schemes were explored:

- Traditional contracting out: The national government and other governments are involved in joint decision making and specify the output they need, the optimal scope of the project, and the kind of cooperation they wish to establish with private parties. Following this, a contracting-out scheme may be set up.

- The combination model: Governments and private parties are involved in decision making at an early stage, but still develop separate ways for public and private decision making.

- The partnering model: Governments and private parties set up a joint platform in which all parties participate on a risk-bearing basis. Together, they specify the projects needed for further development of Mainport Rotterdam, and together they will be responsible for contracting out parts of the plan.

All three models have been elaborated in the PMR process (scheme 3). The PMR management gave preference to the combination model. They began a kind of exploratory round, in which private parties could submit proposals for projects that would be judged by their eco- nomic and social merits. In the end, however, the government did not set up any of these more innovative models, but opted for the traditional approach instead. There were several reasons for this course of action. First of all, the municipality of Rotterdam, which owned the Harbor Authority and thus was accustomed to exploiting and controlling developments in the harbor to an important extent, did not want to lose control of the financial revenues it received from the harbor.

Furthermore, the state committee responsible for the $\mathrm{PKB}+$ procedure was not in favor of the early participation of private parties. Using formal arguments from public law, it chose to stick to traditional procedures. This made any form of partnership extremely difficult. Third, the environmental movement feared that environmental objectives would be neglected in the case of a partnership scheme. Solutions for the intensified use of industrial areas in the port (in terms of underground oil storage, more stacking of containers, etc.) were likely to be rejected by private parties. Thus, the environmental movement advocated a more active position on the part of public actors that would place more pressure on private actors to improve living conditions in the surrounding environment.

\section{Lessons Drawn From Three Generations of Schemes in Search for Partnership}

When analyzing the decision-making process regarding Mainport Rotterdam so far, we may draw some interesting conclusions on governance and partnership:

- Increased complexity of policy making is unmistakable reality. Due to the emancipation of local and regional governments, citizens, and all kinds of private partners, the number of parties involved in decision making has clearly increased.

- This complexity is not just due to the fact that many actors are involved. It also has to do with the development of different perceptions on the problem and preferable solutions and strategies. National government has tried to solve the question of the need and necessity of Mainport development and a new polder by way of the VERM debate. It is still, however, faced with the

\section{Scheme 3 Three Forms of Private Involvement in Spatial-Development Projects}

\begin{tabular}{|ll}
\hline $\begin{array}{l}\text { Variable } \\
\text { Role government }\end{array}$ & $\begin{array}{l}\text { Contracting out } \\
\text { Governments specify what is needed }\end{array}$ \\
Rocess characteristics & $\begin{array}{l}\text { Tendering procedure leading to } \\
\text { contracting out }\end{array}$ \\
Action & Private production of specified project \\
& $\begin{array}{l}\text { Finished job handed over to } \\
\text { government }\end{array}$ \\
\hline
\end{tabular}

\section{Combination model}

Global definition of governmental aims

Early tendering procedure choosing the best private proposal even though a definitive public decision making is not available

Private proposal in interaction with public decision making

Project realization by private companies

Partnering model
A joint public-private platform
specifies the projects needed
Joint principal position in relation to
parties who tender for parts of the
projects
Joint development by private and
public organizations
Joint schemes for production and
exploitation


ongoing debate about the advantages of the development of the Mainport, the transition from Mainport to brainport, and so on. Moreover, the government itself is unable to take a clear position in this debate. Our conclusion is that the Mainport Rotterdam case clearly shows that the number of requirements for development is constantly growing. It is for this reason that we have formulated the twofold goal given above; moreover, the specification of what should be done is undergoing constant change.

- These constant alterations in the inputs and desired outputs of processes, in positive terms, one could say an ongoing learning process, make it difficult to implement a traditional contracting-out scheme (Klijn and Teisman 2000). From this it might be concluded that partnerships are indeed called for. At the same time, however, we may observe that governments are strongly dedicated to their own procedures such as $\mathrm{PKB}+$. In practice, this is likely to lead to situations in which governments refrain from partnerships, because sooner or later these schemes will challenge the formal procedures (based on the centrality of government rather than on joint undertakings).

- Despite all the rhetoric and debate about governance and partnership, the policy making of the Mainport Rotterdam is still rather traditional. Some forms of public cooperation do exist, but they are not yet very powerful. There has been some popular participation, but these activities were too loosely coupled to existingand still rather dominant-political decision making. And although public-private partnership schemes have been investigated more intensively, in the end they were not implemented.

\section{Conclusion: Contradictions and Possibilities}

There have been repeated calls for a shift from a government to a governance approach in general, and partnerships in particular. There are impressive arguments for this shift. Governance could be the public answer to the rise of network society. At the same time, however, practice shows us that existing governmental organizations are not yet capable of developing such partnership schemes in practice. Governance strategies, such as public-private partnerships, call for an exchange of information between actors and a willingness to look for solutions on a mutual basis. Government does not act this way: It recognizes the need for cooperation, but it does not take the consequences. It is for this reason that ideas for public-private partnership are, in practice, transformed into contracting-out schemes. This last type of arrangement meets the need for clear goals defined by government and politicians, clear product specifications, and clear rules for tendering.
The decision-making process of Mainport Rotterdam indicates how difficult it is to establish a partnership, in spite of all the sincere efforts made by public and private officials. Public actors want to retain their primacy within the process. As long as this is the case, private partners will not bring in their knowledge and their efforts. This is a serious obstacle to achieving synergy and finding new solutions. It certainly cannot be precluded that the problems with the Maasvlakte I (no users and an extensive use) will by copied again.

\section{Future Possibilities}

In order to realize the full potential of governance arrangements and public-private partnership, a long road is still ahead. We are dedicated to our traditional representative democracy, and therefore on our guard with respect to more complex governance arrangements. We cherish the different roles of public and private sector, and therefore create clear borders.

The exploration of how to create new governance arrangements, more mature forms of popular participation, and effective public-private partnerships has only just begun. In order to understand the abilities of and problems with governance arrangements, scholars in public administration first should shift from a focus on governmental organizations and the internal procedures to a focus on the interorganizational processes that shape a growing amount of public policy. The importance of process analyses has already been recognized in business administration (Hammer and Champy 1994; Short and Venkatraman 1992; Riggins and Mukhopadhayay 1994). It seems necessary to us that public administration also embraces interorganizational process as an important object for theorizing. From these new theories on governance, we can deal with the interesting dilemma of achieving new types of partnership in order to improve the quality of policy output and being accountable at the same time. In the meantime, governments should ask themselves whether it would be fruitful to become more dedicated to interorganizational processes and less to their own internal procedures. 


\section{References}

Alter, Christine, and Jeremy Hage. 1993. Organizations Working Together. Newbury Park, CA: Sage Publications.

Böttcher, Roeland. 1995. Global Network Management, ContextDecision-Making - Co-Ordination. Wiesbaden: Gabler.

Bryson, John M., and Barbara C. Crosby. 1992. Leadership for the Common Good; Tackling Public Problems in a Shared-Power World. San Francisco, CA: Jossey-Bass.

Castells, Manuel. 1996. The Rise of the Network Society: Economy, Society and Culture. Cambridge: Blackwell Publishers.

Daemen, Harry, and Linze Schaap, eds. 2000. Citizen and City: Developments in Fifteen Local Democracies in Europe. Delft: Eburon.

Falconer, Peter K., and Kathleen McLaughlin. 2000. Public-Private Partnerships and the "New Labour": Government in Britain. In Public-Private Partnerships: Theory and Practice in International Perspective, edited by Stephen P. Osborne, 120-33. London: Routledge

Faulkner, David. 1995. International Strategic Alliances. London: McGraw-Hill.

Giddens, Anthony. 1998. The Third Way. Cambridge: Polity Press.

Graeber, Gernot, ed. 1993. The Embedded Firm; Understanding Networks: Actors, Resources and Processes in Interfirm Cooperation. London: Routledge.

Hakansson, Hakan, and Jan Johansson .1993. The Network as a Governance Structure; Interfirm Cooperation beyond Markets and Hierarchies. In The Embedded Firm; Understanding Networks: Actors, Resources and Processes in Interfirm Cooperation, edited by Gernot Graeber, 35-51. London: Routledge.

Hammer, Michael, and James Champy. 1994. Reengineering the Cooperation: A Manifesto for Business Revolution. New York: Harper Business.

Hanf, Kenneth, and Fritz W. Scharpf, eds. 1978. Interorganizational Policy Making; Limits to Coordination and Central Control. London: Sage Publications.

Hoogervorst, Johannes A.P. 1998. Quality and Customer Oriented Behavior: Towards a Coherent Approach for Improvement. Delft: Eburon.

Kickert, Walter J.M., Erik-Hans Klijn, and Joop F.M. Koppenjan, eds. 1997. Managing Complex Networks; Strategies for the Public Sector. London: Sage Publications.

Klijn, Erik-Hans, and Geert R. Teisman. 2000. Governing PublicPrivate Partnerships: Analysing and Managing the Processes and Institutional Characteristics of Public-Private Partnerships. In Public-Private Partnerships; Theory and Practice In International Perspective, edited by Stephen P. Osborne, 184-201. London: Routledge.

Klijn, Erik-Hans, Joop F.M. Koppenjan, and Katrien J.A.M. Termeer. 1995. Managing Networks in the Public Sector. Public Administration 73(3): 437-54.

Lissack, Michael, and Hugh P. Gunz, eds. 1999. Managing Complexity in Organizations: A View in Many Directions. Westport, CT: Quorum Books.

Lundvall, Bengt Ake. 1993. Explaining Interfirm Cooperation; Limits of the Transaction-Cost Approach. In The Embedded Firm; Understanding Networks: Actors, Resources and Processes in Interfirm Cooperation, edited by Gernot Graeber, 52-64. London: Routledge.

Marsh, David, and Rod A.W. Rhodes, eds. 1992. Policy Networks in British Governments. Oxford: Clarendon Press.

Martin, David M. 1994. Delaying with Demanding Customers; How to Turn Complaints into Opportunities. London: Pitman Publishing.
Mayntz, Renate, and Fritz W. Scharpf. 1973. Planungsorganisation: die Diskussion um die Reform von Regierung und Verwaltung des Bundes (Planning organization: A debate on the reform of government and administration of Germany). München: Piper.

McCarthy, John. 1998. Consensus-Building in Urban Regeneration: Recent Practice in Scotland. Paper presented at XII AESOP Conference, Aveiro, Portugal.

Miles, Raymond E., and Charles C. Snow. 1986. Organization: New Concepts for New Forms. California Management Review 28(3).

Ministerie van VROM. 1990. Actieplan gebiedsgericht milieubeleid (Action plan area oriented environmental policy). Den Haag: Sdu.

Ohmae, Kenichi. 1994. The Borderless World. London: HarperCollins Publishers.

Osborne, Stephen P., ed. 2000. Public-Private Partnerships; Theory and Practice in International Perspective. London: Routledge.

Pressman, Jeffrey L., and Aaron Wildavsky. 1984. Implementation. Berkeley, CA: University of California Press.

Rhodes, Rod A.W. 1988. Beyond Westminster and Whitehall; The Subsectoral Governments of Britain. London: Unwin Hymann. . 1996. The New Governance: Governing without Government. Political Studies 44(4): 652-67.

Riggins, Frederick J., and Tridas Mukhopadhyay. 1994. Interdependent Benefits from Inter-Organizational Systems: Opportunities for Business Partner Reengineering. Journal of Management Information Systems 11(2): 37-57.

ROM project Rijnmond. 1993. Plan van Aanpak; Beleidsdocument (Implementation plan). Den Haag: Sdu.

Scharpf, Fritz W. 1978. Interorganizational Policy Studies: Issues, Concepts and Perspectives. In Interorganizational Policy Making; Limits to Coordination and Central Control, edited by Kenneth Hanf and Fritz W. Scharpf, 345-70. London: Sage Publications.

1997. Games Real Actors Play; Actor-Centered Institutionalism in Policy Research. Boulder, CO: Westview Press.

Short, James E., and N. Venkatraman. 1992. Beyond Business Process Redesign: Redefining Baxter's Business Network. Sloan Management Review 34(1): 7-21.

Sinnig, Herman 1995. Verfahrensinnovationen kooperativer Stadtund Regionalentwicklung (Innovations in cooperative procedures for urban and regional development). Raumforschung und Raumordnung 3: 169-76.

Susskind, Lawrence, and Jeffrey Cruikshank. 1987. Consensual Approaches to Resolving Public Disputes. New York: Basic Books.

Tatenhove, Jan Van. 1993. Milieubeleid onder Dak (Environmental policy accommodated). Wageningen: Agricultural University.

Teisman, Geert R. 1997. Sturen via creatieve concurrentie (Governance by creative competition). Nijmegen: Katholieke Universiteit.

. 2000. Models for Research into Decision-Making Processes: On Phases, Streams and Decision-Making Rounds. Public Administration 78(4): 937-56.

— 2001. Ruimte mobiliseren voor coöpetitief besturen, over management in netwerksamenlevingen (Creating abilities for cooperative governance processes). Inaugural speech, Erasmus University, Rotterdam.

Teisman, Geert R., and Erik-Hans Klijn. 2000. Public-Private Partnerships in the European Union: Officially Suspect, Embraced in Daily Practice. In Public-Private Partnerships; Theory and Practice in International Perspective, edited by Stephen P. Osborne, 165-86. London: Routledge. 